\title{
Disseminated tuberculosis following immunosuppressive therapy for nephrotic syndrome
}

\author{
R S Thalgahagoda ${ }^{1}$, A H H M Jayaweera ${ }^{1}$, S Abeyagunawardena ${ }^{2}$, U I. Karunadasa ${ }^{2}$, *A S \\ Abeyagunawardena ${ }^{2}$
}

Sri Lanka Journal of Child Health, 2019; 48(1): 77-79

DOI: http://dx.doi.org/10.4038/sljch.v48i1.8658

(Keywords: Nephrotic syndrome, immunosuppressive therapy, disseminated tuberculosis, latent tuberculosis, reactivation)

\begin{abstract}
Introduction
Over $80 \%$ cases of nephrotic syndrome (NS) in children are due to minimal change disease and most respond to steroid therapy ${ }^{1}$. Steroid sensitive NS rarely progresses to end stage renal failure, over $80 \%$ entering spontaneous long term remission in later childhood ${ }^{2}$. In contrast, steroid resistant and refractory NS have an unfavourable outcome often progressing to end stage renal failure ${ }^{3,4}$. Infection is a universal concern in patients receiving cytotoxic or immunosuppressive therapy. Concomitant glucocorticoid therapy adds to this problem and the risk of infection with cytomegalovirus, Pneumocystis carinii, and varicella zoster is always present ${ }^{5}$. It is well known that severe attack of measles can re-activate tuberculosis ${ }^{6}$ and this case report describes its reactivation following immunosuppressive therapy for NS.
\end{abstract}

\section{Case report}

An eleven year old boy was referred to the Tertiary Care Nephrology Centre of the University of Peradeniya for further management of his initial episode of NS. He was treated with prednisolone $60 \mathrm{mg} / \mathrm{m}^{2 /}$ day for 6 weeks but nephrotic range proteinuria $(2.43 \mathrm{mg} / \mathrm{mmol})$ continued. He was oedematous, the serum albumin was $12 \mathrm{~g} / \mathrm{L}$ and he had a urine output of $0.3 \mathrm{ml} / \mathrm{kg} /$ hour. He had persistent hypertension and with antihypertensive therapy his BP was 130/80 $\mathrm{mmHg}$. His hepatitis B surface antigen and antinuclear antibody were negative and the complement assay was normal. He underwent

\footnotetext{
$\overline{{ }^{1} \text { Faculty of Medicine, University of Peradeniya, }}$ Sri Lanka, ${ }^{2}$ Teaching Hospital Peradeniya, Sri Lanka

*Correspondence: asiriabey26@gmail.com (Received on 21 March 2017: Accepted after revision on 19 May 2017)

The authors declare that there are no conflicts of interest

Personal funding was used for the project.

Open Access Article published under the Creative

Commons Attribution CC-BY cc (i)
}

renal biopsy which revealed focal and segmental glomerulosclerosis. Hence he was commenced on 3 pulses of methyl prednisolone at $600 \mathrm{mg} / \mathrm{m}^{2}$ /daily and monthly pulses of intravenous cyclophosphamide at $600 \mathrm{mg} / \mathrm{m}^{2}$.

Oral corticosteroid therapy was continued at $60 \mathrm{mg} / \mathrm{m}^{2}$ on alternate days for 4 weeks tapering $10 \mathrm{mg} / \mathrm{m}^{2}$ monthly. Oedema was initially controlled with the use of diuretics and after the second pulse of cyclophosphamide the child finally entered complete remission. After being in remission for 5 days, he was to be discharged after a prolonged hospital stay. However, on the day of discharge before leaving hospital he became unwell with cough and vomiting. He was commenced of intravenous fluids and the initial chest $\mathrm{x}$-ray revealed opacities of the right lung with hilar lymphadenopathy (figure 1).

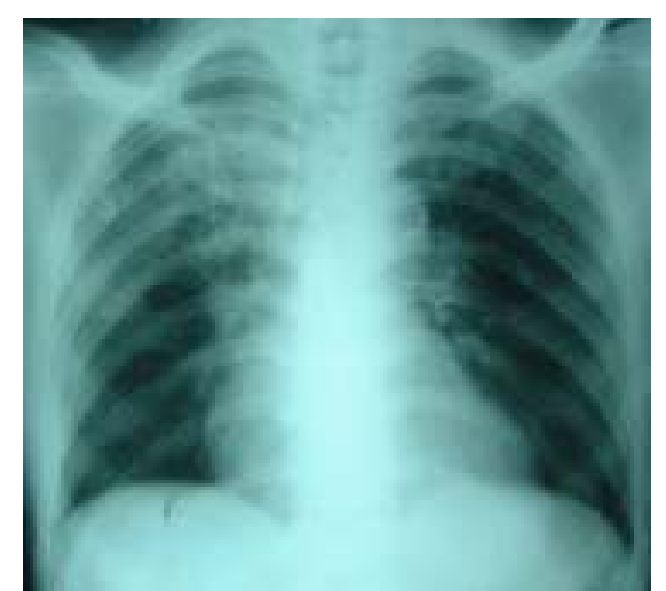

Figure 1: Chest $x$-ray revealing opacities of right lung with hilar lymphadenopathy

Thus he was commenced on intravenous cefuroxime. However, his clinical condition deteriorated rapidly and the chest X-ray done 24 hours later demonstrated complete opacification of the right lung. He was commenced on intravenous meropenem and received intensive care. His erythrocyte sedimentation rate was $133 \mathrm{~mm}$ in the first hour and the polymerase chain reaction for Mycobacterium tuberculosis was positive in 
blood. The patient succumbed and the postmortem examination revealed disseminated tuberculosis.

\section{Discussion}

The activation of indolent TB during immunosuppressive therapy has received much emphasis in the western literature ${ }^{7,8}$ but has always been a cause for concern in India. It is important to have a high degree of suspicion of the possibility of re-activation of TB during heavy immunosuppressive therapy especially in steroid resistant disease. Cytotoxic and immunosuppressive drugs while playing a pivotal role in induction and maintenance of remission in some types of NS in children, are themselves associated with significant morbidity. The risk of associated side effects is more pronounced in steroid resistant nephrotic syndrome (SRNS) and steroid dependent nephrotic syndrome (SDNS) where children are exposed to multiple courses of high-dose prednisolone. Glucocorticoids are known to strongly reduce the production of cytokines IL$1 \beta$ and $\mathrm{TNF}-\alpha$, and many immunomodulatory cytokines such as IL-2, IL-10, IL-12 and IFN- $\gamma$ whereas cyclosporine and tacrolimus inhibit $\mathrm{T}$ cell function and IL- 2 production ${ }^{9}$. TNF- $\alpha$ is a key cytokine in host defence mechanism against Mycobacterium tuberculosis ${ }^{10}$. Prolonged treatment with cytotoxic drugs such as cyclophosphamide and chlorambucil also places the patient at highly immunocompromised state. In a person with latent $\mathrm{TB}$ infection, such a shift in the immunological status can cause the $M$. tuberculosis bacteria to multiply further, resulting in disease which manifests as active $\mathrm{TB}^{11}$.

Given this proven increased risk of TB activation, screening patients for latent infection should take place before starting longterm immunosuppressive therapy. However currently a gold standard for such screening is lacking. The two main available tests are the tuberculin skin test (TST) and interferon- $\gamma$ release assays (IGRAs). Though TST shows high sensitivity in individuals with normal immune responses ${ }^{12}$ the sensitivity in people with previous Bacille Calmette-Guérin (BCG) vaccination, prior exposure to nontuberculous mycobacteria and immunosuppressant medication is lower ${ }^{7}$. Though some studies suggest the T-SPOT blood test which is a type of IGRA to diagnose latent $\mathrm{TB}^{7,13}$, a study by Ratnatunga et al in Sri Lanka showed no advantage in using T-SPOT.TB over $\mathrm{TST}^{14}$. The TST is the most widely used method for TB screening in these settings due to the significant advantage of low cost.

Despite the lack of a golden standard, the need for TB screening prior to heavy immunosuppressive therapy especially in children, remains important. Tuberculosis skin test, smear microscopy and chest radiography could be employed for this purpose, preferably after an individual risk assessment for each patient. It should also be taken into account that prophylactic therapy for TB carries a low risk of hepatotoxicity, which is also an undesirable side-effect of cyclophosphamide ${ }^{15}$.

\section{References}

1. Churg J, Habib R, White RH. Pathology of the nephrotic syndrome in children: a report for the International Study of Kidney Disease in Children. Lancet 1970; 760:1299-302.

https://doi.org/10.1016/S01406736(70)91 905-7

2. Tarshish $\mathrm{P}$, Tobin JN, Bernstein J, Edelmann CM Jr. Prognostic significance of the early course of minimal change nephrotic syndrome: report of the International Study of Kidney Disease in Children. Journal of the American Society of Nephrology 1997; 8:769-76. PMid: 9176846

3. Sinha M, MacLeod R, Rigby E, Clark A. Treatment of severe steroid-dependent nephrotic syndrome (SDNS) in children with tacrolimus. Nephrology Dialysis Transplantation. 2006; 21:1848-54. https://doi.org/10.1093/ndt/gfi274 PMid: 16311257

4. Mekahli D, Liutkus A, Ranchin B, Yu A, Bessenay L, Girardin E et al. Long-term outcome of idiopathic steroid-resistant nephrotic syndrome: a multicenter study. Pediatric Nephrology. 2009; 24:1525-32. https://doi.org/10.1007/s00467-009-11385

PMid: 19280229

5. Latta K, von Schnakenburg C, Ehrich JH. A meta-analysis of cytotoxic treatment for frequently relapsing nephrotic syndrome in children. Pediatric Nephrology 2001; 16:271-82.

https://doi.org/10.1007/s004670000523

PMid: 11322378 
6. Smith H, Sweet C. Cooperation between viral and bacterial pathogens in causing human respiratory disease. In: Brogden KA, Guthmiller JM, editors. Polymicrobial Diseases. Washington (DC): ASM Press; 2002. Chapter 11. Available from: https://www.ncbi.nlm.nih.gov/books/NB K2479/

https://doi.org/10.1128/9781555817947.c h11

7. Hassanzadeh R, France J, Bawa S. Targeted Screening for Latent TB Infection prior to Biologic Therapy to Improve Patient Safety and Reduce Costs: A Prospective Observational Study. ISRN Infectious Diseases 2014; 2014:1-6. https://doi.org/10.1155/2014/378908

8. Jick S, Lieberman E, Rahman M, Choi H. Glucocorticoid use, other associated factors, and the risk of tuberculosis. Arthritis \& Rheumatism 2006; 55(1):1926.

https://doi.org/10.1002/art.21705

PMid: 16463407

9. Mottram P. Past, present and future drug treatment for rheumatoid arthritis and systemic lupus erythematosus. Immunology and Cell Biology 2003; 81(5):350-3.

https://doi.org/10.1046/j.14401711.2003. 01184.x

PMid: 12969322

10. Lalvani A, Millington K.A. T cells and tuberculosis: beyond interferongamma. Journal of Infectious Diseases 2008; 197:941-3. https://doi.org/10.1086/529049

PMid: 18419531
11. Mack U, Migliori G, Sester M, Rieder H, Ehlers S, Goletti D et al. LTBI: latent tuberculosis infection or lasting immune responses to $\mathrm{M}$. tuberculosis? A TBNET consensus statement. European Respiratory Journal 2009; 33(5):956-73. https://doi.org/10.1183/09031936.001209 08 PMid: 19407047

12. Rose DN, Schecter CB, Adler JJ. Interpretation of the tuberculin skin test. Journal of General Internal Medicine 1995; 10: 635-42. https://doi.org/10.1007/BF02602749 PMid: 8583267

13. Pai M. Systematic Review: T-Cell-based Assays for the Diagnosis of latent tuberculosis infection: An update. Annals of Internal Medicine 2008; 149(3):177. https://doi.org/10.7326/0003-4819-149-3200808050-00241

PMid: 18593687 PMCid: PMC2951987

14. Ratnatunga C, Thevanesam V, Madegedara D, Dissanayake N, Kumara K. T-SPOT. TB assay and tuberculin skin test for diagnosis and screening of tuberculosis: First report in a Sri lankan population. Asian Journal of Medical Sciences 2015; 7(1):14.

https://doi.org/10.3126/ajms.v7i1.12595

15. Ghafor H. Low-dose cyclophosphamideinduced acute hepatotoxicity. American Journal of Case Reports 2013; 14:345-9. https://doi.org/10.12659/AJCR.889401 PMid: 24023976 PMCid: PMC3767583 